\title{
Mass Spectral Fragmentation of Pelargonium graveolens Essential Oil Using GC-MS Semi-Empirical Calculations and Biological Potential
}

\author{
Mamoun S.M. Abd El-Kareem ${ }^{1}{ }^{\mathbb{D}}$, Mohamed A. Rabbih ${ }^{1}$, Hosam O. Elansary ${ }^{2,3, * \mathbb{C}}$ and \\ Fahed A. Al-Mana ${ }^{2}$ \\ 1 Molecular and Atomic Physics Unit, Experimental Nuclear Physics Dept, Nuclear Research Centre, Egyptian \\ Atomic Energy Authority, Cairo 13759, Egypt; mamoun_sarhan@yahoo.com (M.S.M.A.E.-K.); \\ m.a.rabbih@gmail.com (M.A.R.) \\ 2 Plant Production Department, College of Food and Agricultural Sciences, King Saud University, \\ P.O. Box 2455, Riyadh 11451, Saudi Arabia; falmana@ksu.edu.sa \\ 3 Floriculture, Ornamental Horticulture, and Garden Design Department, Faculty of Agriculture (El-Shatby), \\ Alexandria University, Alexandria 21545, Egypt \\ * Correspondence: helansary@ksu.edu.sa; Tel.: +966-581-216-322
}

Received: 7 January 2020; Accepted: 20 January 2020; Published: 21 January 2020

\begin{abstract}
The volatile constituents of the essential oil of local Pelargonium graveolens growing in Egypt was investigated by gas chromatography-mass spectrometry (GC-MS), and the main constituents were citronellol (27.67\%), cis-Menthone (10.23\%), linalool (10.05\%), eudesmol $(9.40 \%)$, geraniol formate $6.87 \%$, and rose oxide $(5.77 \%)$, which represent the major components in the obtained GC total ion chromatogram. The structural determination of the main constitutes based on their electron ionization mass spectra have been investigated. The MS of these compounds are absolutely identical in mass values of peaks of fragment ions, where their relative intensities have minor differences. In the spectra of all studied compounds, the observed characteristic ions were $\left[\mathrm{M}-\mathrm{H}_{2} \mathrm{O}\right]^{+}$and $\left[\mathrm{M}-\mathrm{CH}_{3}\right]^{+}$. The latter has a structure with $\mathrm{m} / \mathrm{z}$ 69, 83. Different quantum parameters were obtained using Modified Neglect of Diatomic Overlap (MNDO) semi-empirical method as total energy, binding energy, heat of formations, ionization energy, the energy of highest occupied molecular orbital (HOMO), the energy of the lowest unoccupied molecular orbital (LUMO), energy gap $\Delta$, and dipole moment. The antibacterial and antifungal activities of $P$. graveolens essential oil and identified compounds were tested against wide collection of organisms. The individual identified compounds in the essential oil—citronellol, cis-Menthone, and linalool (except eudesmol)—showed comparable activity to antibiotics. The most active isolated compound was the citronellol and the lowest MIC was found against E. coli. The essential oil showed high antifungal effects and this activity was attributed to cis-Menthone, eudesmol, and citronellol (excluding linalool). cis-Menthone was the most active compound against selected fungi followed by the eudesmol The study recommends local $P$. graveolens and identified active compounds for further applications in the pharmaceutical industries.
\end{abstract}

Keywords: essential oils; Pelargonium graveolens; gas chromatography-mass spectrometry; semi-empirical calculations; antibacterial; antifungal

\section{Introduction}

Essential oils are natural complex and volatile compounds that are produced by plants as secondary metabolites that may control pests, bacteria, fungi, and viruses [1-3]. The antifungal, antioxidant, antitumor, antiviral, and antibacterial activities of these compounds is widely studied [4-7]. Pelargonium graveolens (Geraniaceae) is a species in the Pelargonium genus, whichs contain $\sim 250$ species originated 
from South Africa and is often called a geranium. The essential oil of $P$. graveolens is one of the most expensive essential oils used in the perfumery, flavoring, and cosmetics [8].

Mass spectrometry (MS) techniques have an important role in the development of natural products industry over the five decade. It provided a starting point for the identification or structure determination of the most of natural products as well as the molecular weight [9]. MS techniques can provide a lot of structural information with little expenditure of the studied molecules based on their electron ionization (EI) mass spectra and electron ionization (EI) mass spectra [10]. The fragmentation of ionized molecule depends mainly on their internal energy [11]. Also, semi-empirical (MNDO) is a quantum mechanical method for the determination of thermochemical properties of molecules used in chemistry and physics to determine the electronic structure of molecules, and represents the most successful method to calculate the structure of matter and complement experimental investigations [12-14]. The chemical composition of the essential oil using gas chromatograph mass spectrometer (GC-MS) of different Pelargonium species such as P. odoratissimum and P. graveolens have been reported $[15,16]$. However, to the best of our knowledge, neither complete mass spectra nor structure elucidation of the essential oil constituents of $P$. graveolens using EI mass spectra have been reported. Further, the thermodynamics properties of these essential oil constituents using MNDO calculations have not been reported before [16-18].

Bacterial and fungal infections may cause severe diseases in humans and animals $[1,19,20]$. Secondary metabolites, including essential oils, are considered natural products commonly used to control fungal and bacterial diseases $[1,2,7,21,22]$. P. graveolens essential oils had been reported in few studies; however, a full picture of the activity and the magnitude of each major essential oil constitute as antimicrobial agent had not been investigated before [15-18]. Furthermore, the large number of species belonging to Pelargonium and ecotype variation influenced the results of these studies.

The aim of the present study is to investigate the use of GC-MS in the identification of the chemical composition of P. graveolens essential oils and to elucidate the molecular structure of the main essential oil constituents based on their electron ionization mass spectra. In addition, we applied the theoretical MNDO calculations, including geometrical structures optimization and thermodynamic parameters. The obtained data will aid in understanding the bioactivity of the studies components. Further, this study aims to investigate individual essential oil constitutes antimicrobial activities against different bacteria and fungi.

\section{Results and Discussion}

\subsection{GC-MS}

The total ion chromatogram recorded by GC-MS of the P. graveolens essential oil is shown in Figure 1, and the total chemical composition is shown in Table S1 (Supplementary Information), which contained 30 identified compounds. These components consist of hydrocarbons (represent $16 \%$ ), such as pinene, limonene, and oxygenated components (with one oxygen atom) represent $72 \%$, and linalool, D-menthone, and oxygenated (with two oxygen atoms) represent $11.5 \%$, such as geraniol formate. The main components in P. graveolens; (R) Citronellol (17.33\%), cis-Menthone $(10.23 \%), \beta$-Linalool (10.05\%), Eudesmol $(9.40 \%)$, geraniol formate $(6.87 \%)$, and rose oxide $(5.77 \%)$. The essential oil composition of obtained in this study is different than other previous studies. Previous investigation on P. graveolens from North India revealed a different composition: citronellol (33.6\%), geraniol (26.8\%), linalool (10.5\%), citronellyl formate (9.7\%), and menthone (6.0\%) [23]. In addition, another report from Tunisia revealed another ratios of major compound: citronellol (21.9\%), citronellyl formate (13.2\%), geraniol (11.1\%), eudesmol (7.9\%), geranyl formate (6.2\%), and (1)-linalool (5.6\%) [24]. There is great diversity with the species ecotypes which is reflected in major essential oil constitutes and biology activities. 


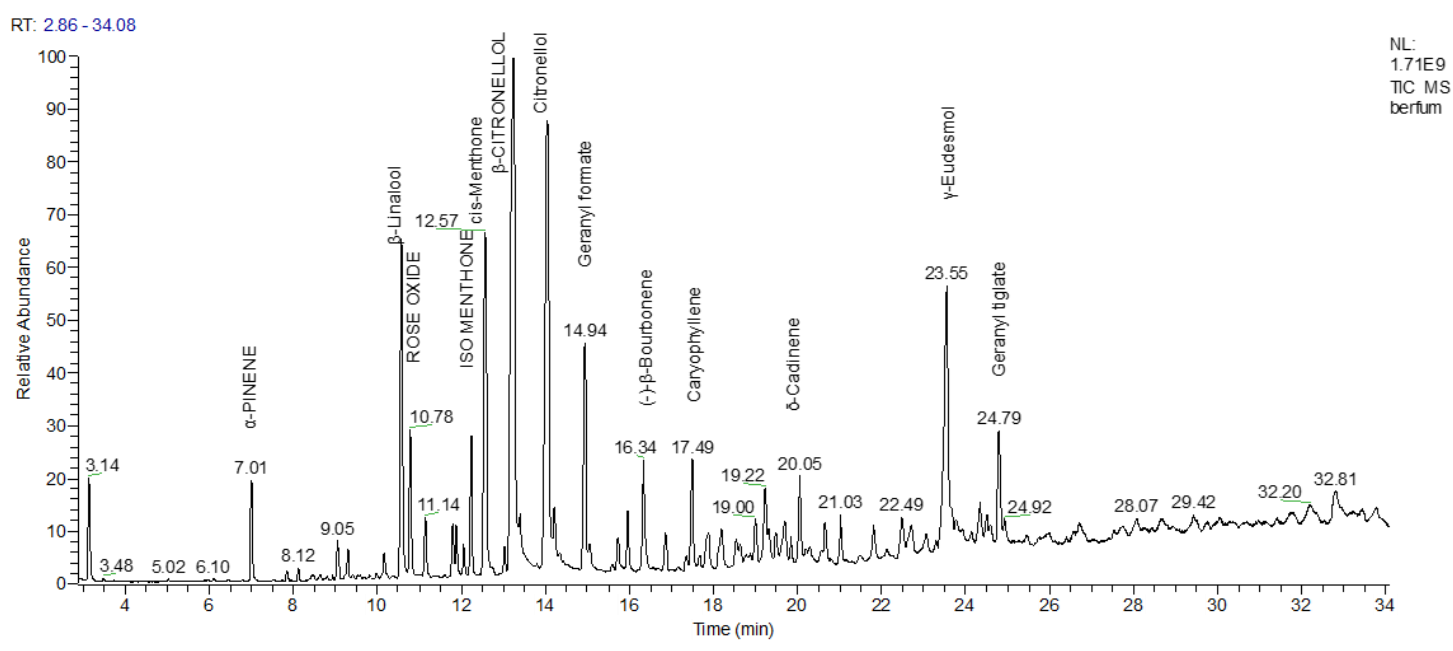

Figure 1. Total ion chromatogram of $P$. graveolens essential oil using GC-MS.

\subsection{Mass Spectrometric Observations about the Fragmentation of the Studied Compounds Under EI Conditions}

The fragmentation of the main components of $P$. Graveolens by electron ionization at $70 \mathrm{eV}$ with single quadruple mass spectrometer based on its mass spectra were reported, as shown as in Scheme 1. The compounds investigated in this study fit into two groups. The first group comprises the compounds citronellol, linalool, and eudesmol, which have a hydroxy $(\mathrm{OH})$ group through its structures. The second group comprises menthone and geraniol formate with oxygen as carbonyl-C-O group. Although the last studied compound (rose oxide) has a hetero oxygen atom in six cyclic ring.

\subsubsection{Fragmentation Pattern of Citronellol Compound}

When studying the mass spectra of all main components of $P$. graveolens essential oil, it could be concluded that the molecular ions of these compounds have low abundance as smaller peaks, which indicates that the molecular ions are unstable at $70 \mathrm{eV}$. The first fragmentation pathway of the molecular ion of citronellol is the formation of the fragment ion at m/z 138 (Scheme 1). This could be could be explained by the formation of $\left[\mathrm{M}-\mathrm{H}_{2} \mathrm{O}\right]^{+\bullet}$ ion, which loses the $\mathrm{H}_{2} \mathrm{O}$ from the molecular ion. In addition, the ion $\left[\mathrm{M}-\mathrm{H}_{2} \mathrm{O}\right]^{+\bullet}$ can be fragment by three ways. First by loss of a $\mathrm{CH}_{3}{ }^{\bullet}$ radical to produce the fragment ion $\left[\mathrm{M}-\mathrm{H}_{2} \mathrm{O}-\mathrm{CH}_{3}\right]^{+}$at $\mathrm{m} / \mathrm{z} 123$. The second way is by the loss of a $\mathrm{C}_{3} \mathrm{H}_{7}{ }^{\bullet}$ radical to produce $\left[\mathrm{M}-\mathrm{H}_{2} \mathrm{O}-\mathrm{C}_{3} \mathrm{H}_{7}\right]^{+}$at $\mathrm{m} / \mathrm{z}$ 95. The third way is by the loss $\mathrm{C}_{4} \mathrm{H}_{9}{ }^{\bullet}$ to produce $\left[\mathrm{M}-\mathrm{H}_{2} \mathrm{O}-\mathrm{C}_{4} \mathrm{H}_{9}\right]^{+}$at $\mathrm{m} / \mathrm{z} 81$.

The second fragmentation pathway of the molecular ion of citronellol is by the simple cleavage to produce directly the fragment ion $\mathrm{C}_{5} \mathrm{H}_{9}{ }^{+}$with $\mathrm{m} / \mathrm{z} 69$, which represents the base peak in the mass spectrum as shown in Figure 2a. 
A. Citronellol

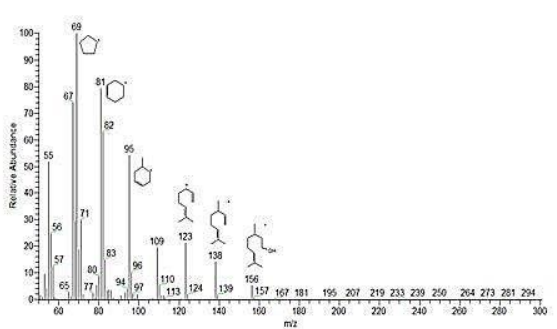

C. D-menthone

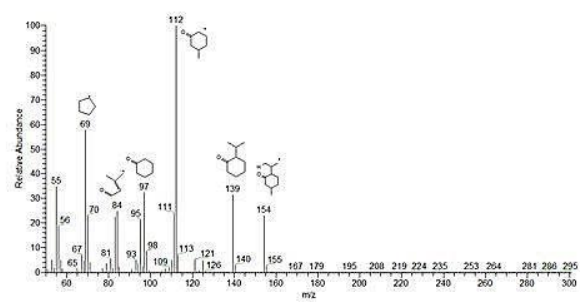

E. Geraniol formate

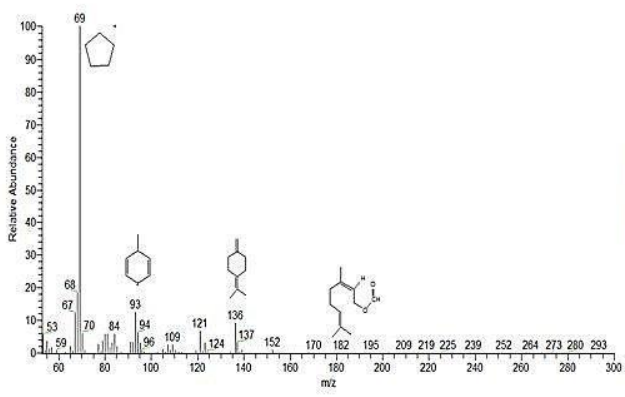

B. Linalool

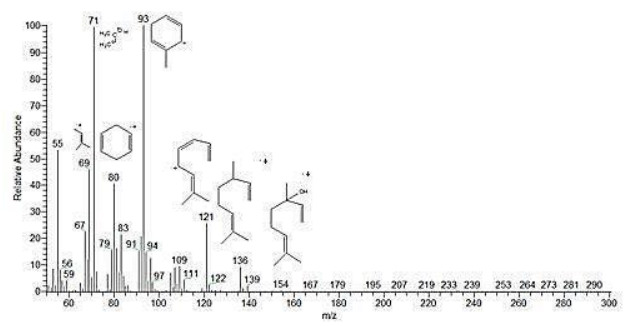

D. Eudesmol

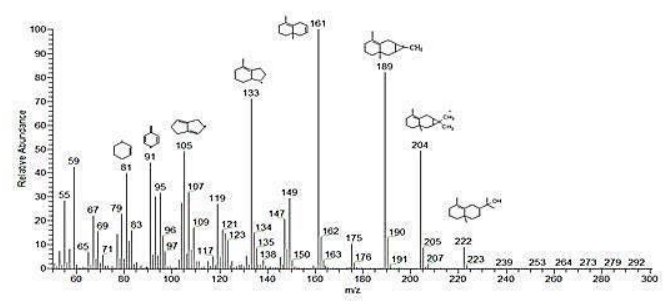

F . Rose oxide

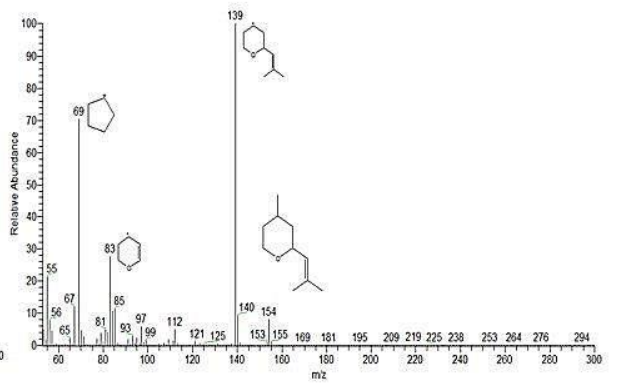

Figure 2. EI Mass Spectra of the studied components of P. graveolens: (A) citronellol, (B) linalool, (C) cis-Menthone, (D) eudesmol, (E) geraniol formate, and (F) rose oxide.

\subsubsection{Fragmentation Pattern of Linalool Compound}

The mass spectrum of linalool shows very low abundance of the molecular ion peak, which could be explained by the instability of the hydroxyl group at $\mathrm{C} 3$ atom. The first fragmentation pathway of the molecular ion of linalool is the formation of the fragment ion at $\mathrm{m} / \mathrm{z} 136$. It is certainly due to the formation of $\left[\mathrm{M}-\mathrm{H}_{2} \mathrm{O}\right]^{+\bullet}$ ion by the loss of $\mathrm{H}_{2} \mathrm{O}$ from the molecular ion. In addition, the fragment ion $\left[\mathrm{M}-\mathrm{H}_{2} \mathrm{O}\right]^{+\bullet}$ could be fragmented by the loss of $\mathrm{CH}_{3} \bullet$ radical to produce the fragment ion $\left[\mathrm{M}-\mathrm{H}_{2} \mathrm{O}-\mathrm{CH}_{3}\right]^{+}$ at $\mathrm{m} / \mathrm{z} 121$. This fragment ion could be fragmented by two ways: First, by loss $\mathrm{C}_{3} \mathrm{H}_{5}$ ' radical to produce $\left[\mathrm{M}-\mathrm{H}_{2} \mathrm{O}-\mathrm{CH}_{3}-\mathrm{C}_{3} \mathrm{H}_{5}\right]^{+}$ion at m/z 80. Second, by the loss of $\mathrm{C}_{2} \mathrm{H}_{4}$ to produce $\left[\mathrm{M}-\mathrm{H}_{2} \mathrm{O}-\mathrm{CH}_{3}-\mathrm{C}_{2} \mathrm{H}_{4}\right]^{+}$ ion at $\mathrm{m} / \mathrm{z}$ 93. In addition, it may be formed directly from $\left[\mathrm{M}-\mathrm{H}_{2} \mathrm{O}\right]^{+\bullet}$ ion by the loss of $\mathrm{C}_{3} \mathrm{H}_{7}{ }^{\bullet}$ radical, which is reflected in the chromatogram with highest peak as shown in Figure $2 b$. The second fragmentation pathway of the molecular ion of linalool is with the simple cleavage to produce directly the fragment ion $\mathrm{C}_{5} \mathrm{H}_{9}{ }^{+}$at $\mathrm{m} / \mathrm{z} 69$ as shown in Scheme 1.

\subsubsection{Fragmentation Pattern of Menthone Compound}

The menthone mass spectrum is shown in Figure 2c. It is clear that the loss of $\mathrm{C}_{3} \mathrm{H}_{6}$ with McLafferty rearrangement is eliminated from menthone molecular ion to form the $\mathrm{C}_{7} \mathrm{H}_{12} \mathrm{O}^{+}$ion at $\mathrm{m} / \mathrm{z}$ 112 , which represents the base peak in the spectrum. This ion is fragmented by the loss of $\mathrm{CH}_{3}{ }^{\bullet}$ radical to form $\mathrm{C}_{6} \mathrm{H}_{9} \mathrm{O}^{+}$ion at $\mathrm{m} / \mathrm{z} 97$, the latter is fragmented by the loss of $\mathrm{CO}$ to form $\mathrm{C}_{5} \mathrm{H}_{9}{ }^{+}$at $\mathrm{m} / \mathrm{z} 69$.

The second fragmentation process of menthone molecular ion is the loss of $\mathrm{CH}_{3} \cdot$ radical directly to form $\mathrm{C}_{9} \mathrm{H}_{15} \mathrm{O}^{+}$ion at $\mathrm{m} / \mathrm{z} 139$, which could be fragmented by the loss of $\mathrm{CO}$ to produce the $\mathrm{C}_{8} \mathrm{H}_{15}{ }^{+}$ 
ion at $\mathrm{m} / \mathrm{z} 111$. On the other hand, the molecular ion could be fragmented directly to form the two fragment ions $\mathrm{C}_{5} \mathrm{H}_{8} \mathrm{O}^{+}$and $\mathrm{C}_{5} \mathrm{H}_{9}{ }^{+}$at $\mathrm{m} / \mathrm{z} 84$ and 69 as shown in Scheme 1, respectively.

\subsubsection{Fragmentation Pattern of Eudesmol Compound}

The most characteristic fragmentation pathway for eudesmol molecular ion is the formation of the fragment ion $\mathrm{C}_{15} \mathrm{H}_{24}{ }^{+\bullet}$ at $\mathrm{m} / \mathrm{z} 204$ in the mass spectrum (Figure 2d), which is certainly due to the ion $\left[\mathrm{M}-\mathrm{H}_{2} \mathrm{O}\right]^{+\bullet}$ as shown in Scheme 1. This fragment ion undergoes fragmentation by two pathways: the first is the formation of the fragment ion $\mathrm{C}_{14} \mathrm{H}_{21}{ }^{+}$at $\mathrm{m} / \mathrm{z} 189$ by the loss of $\mathrm{CH}_{3}{ }^{\bullet}$ radical. The second is the formation of the fragment ion $\mathrm{C}_{12} \mathrm{H}_{17}{ }^{+}$at $\mathrm{m} / \mathrm{z} 161$ by the loss of $\mathrm{C}_{3} \mathrm{H}_{7}{ }^{\bullet}$ radical, which represent the base peak in the mass spectrum. The fragment ion $\mathrm{C}_{12} \mathrm{H}_{17}{ }^{+}$at $\mathrm{m} / \mathrm{z} 161$ undergoes fragmentation by the loss of $\mathrm{C}_{2} \mathrm{H}_{4}$ molecule to form the fragment ion $\mathrm{C}_{10} \mathrm{H}_{13}{ }^{+}$at $\mathrm{m} / \mathrm{z} 133$. This fragment could be fragment by three pathways: first, by the loss of $\mathrm{C}_{2} \mathrm{H}_{4}$ molecule to form the fragment ion $\mathrm{C}_{8} \mathrm{H}_{9}{ }^{+}$at $\mathrm{m} / \mathrm{z}$ 105. Second, by the loss of $\mathrm{C}_{3} \mathrm{H}_{6}$ to form the fragment ion $\mathrm{C}_{7} \mathrm{H}_{7}{ }^{+}$at $\mathrm{m} / \mathrm{z} 91$. Third, by the loss of $\mathrm{C}_{4} \mathrm{H}_{4}$ to form the fragment ion $\mathrm{C}_{6} \mathrm{H}_{9}{ }^{+}$at $\mathrm{m} / \mathrm{z} 81$ as shown in Scheme 1 .

\subsubsection{Fragmentation Pattern of Geraniol Formate Compound}

The electron ionization mass spectrum of geraniol formate shows low relative abundance of the molecular ion peak as shown in Figure 2e. The molecular ion of geraniol formate undergoes fragmentation to form the fragment ion $\mathrm{C}_{5} \mathrm{H}_{9}{ }^{+}$at $\mathrm{m} / \mathrm{z} 69$ directly by simple cleavage which represent the base peak in the spectrum. In addition, the molecular ion could be fragmented with McLafferty rearrangement process by the loss of $\mathrm{H}_{2} \mathrm{CO}_{2}$ to form the fragment ion $\mathrm{C}_{10} \mathrm{H}_{16}{ }^{+}$(monoterpene hydrocarbon) at $\mathrm{m} / \mathrm{z} 136$, which consequently form the fragment ion $\mathrm{C}_{7} \mathrm{H}_{9}{ }^{+}$at $\mathrm{m} / \mathrm{z} 93$ by the loss of $\mathrm{CH}_{3}{ }^{\bullet}$ radical as shown in Scheme 1.

\subsubsection{Fragmentation Pattern of Rose Oxide Compound}

The mass spectrum of the rose oxide gives the molecular ion $\mathrm{C}_{10} \mathrm{H}_{18} \mathrm{O}^{+\bullet}$ at $\mathrm{m} / \mathrm{z} 154$ with small relative intensity as shown in Figure 2f. The first fragmentation process of the molecular ion of rose oxide is the formation of the fragment ion $\mathrm{C}_{9} \mathrm{H}_{15} \mathrm{O}^{+}$at $\mathrm{m} / \mathrm{z} 139$ by the loss of $\mathrm{CH}_{3}$ radical with simple cleavage which represent the base peak in the mass spectrum. The second fragmentation process is to form the fragment ions $\mathrm{C}_{5} \mathrm{H}_{9}{ }^{+}$at $\mathrm{m} / \mathrm{z}$ and $\mathrm{C}_{3} \mathrm{H}_{7} \mathrm{O}^{+}$at $\mathrm{m} / \mathrm{z} 83$, which are formed by hydrogen atom rearrangement processes as shown in Scheme 1. 


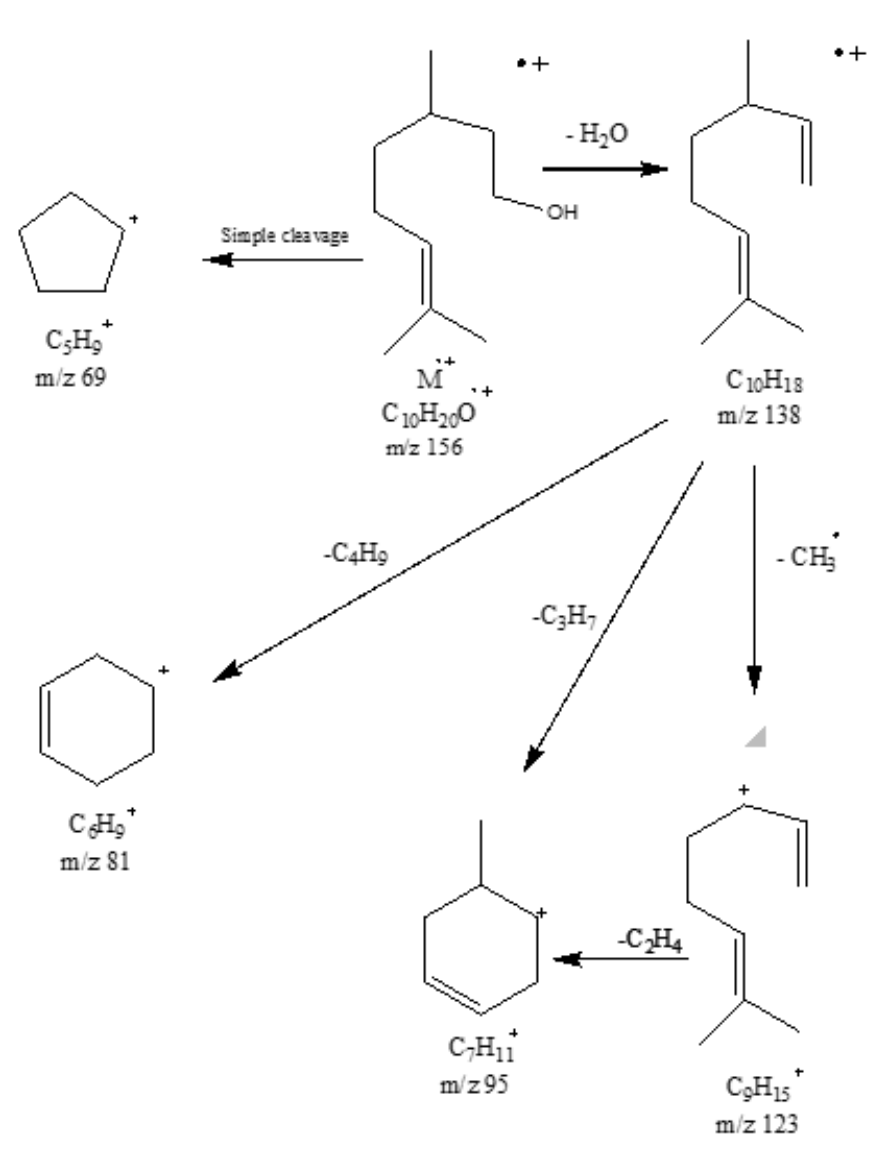

(a) Citronellol

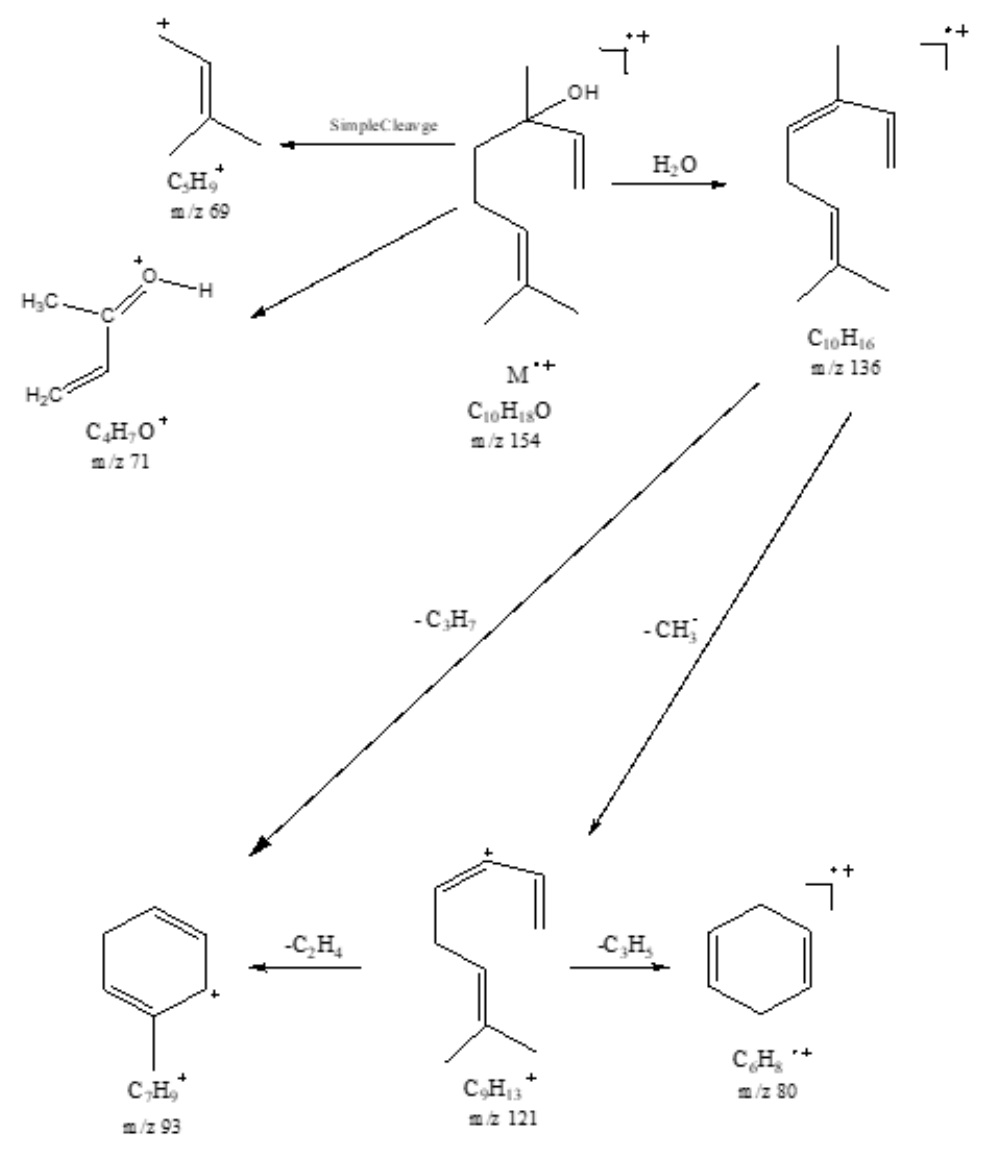

(b) Linalool

Scheme 1. Cont. 


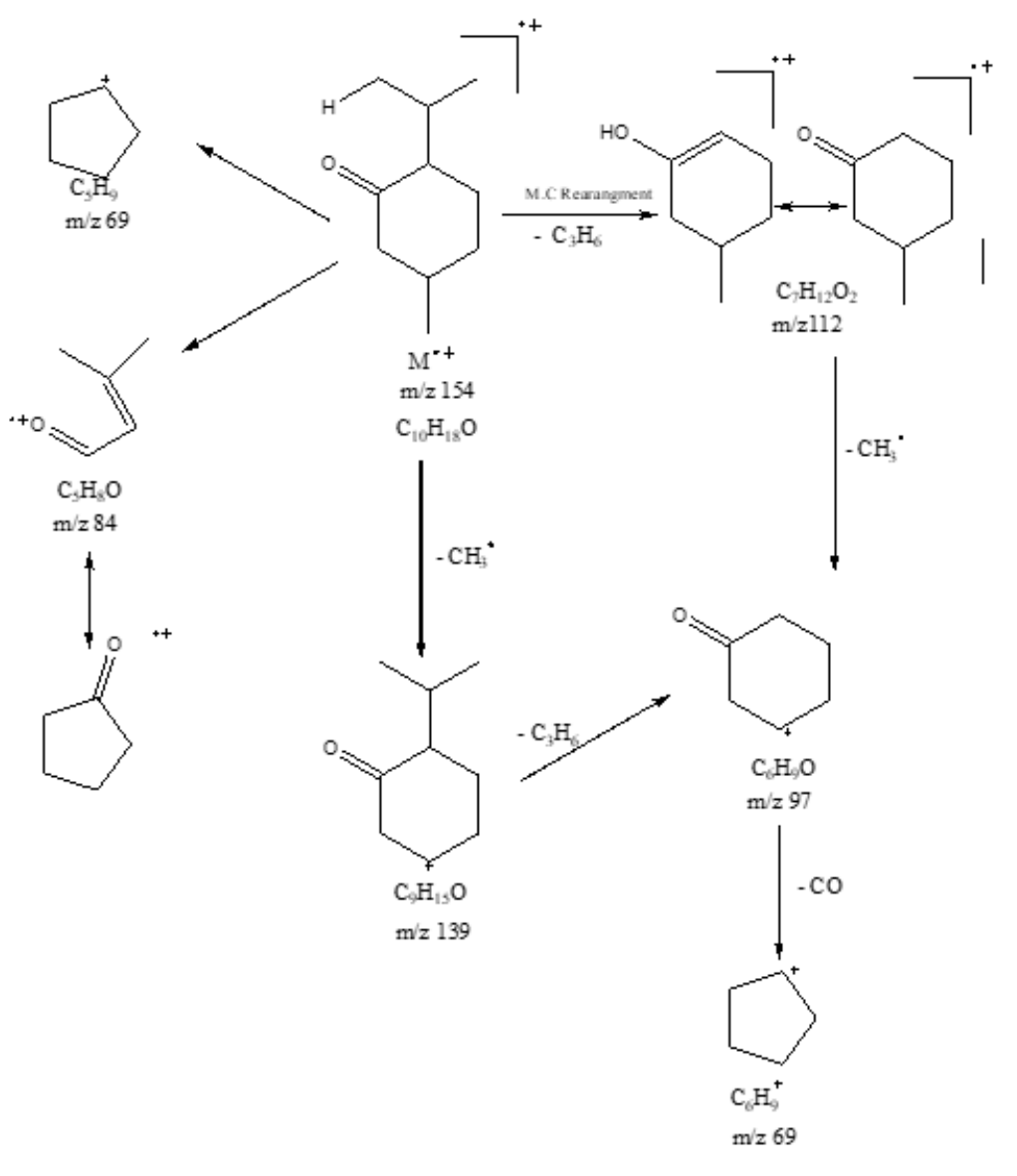

(c) cis-Menthone

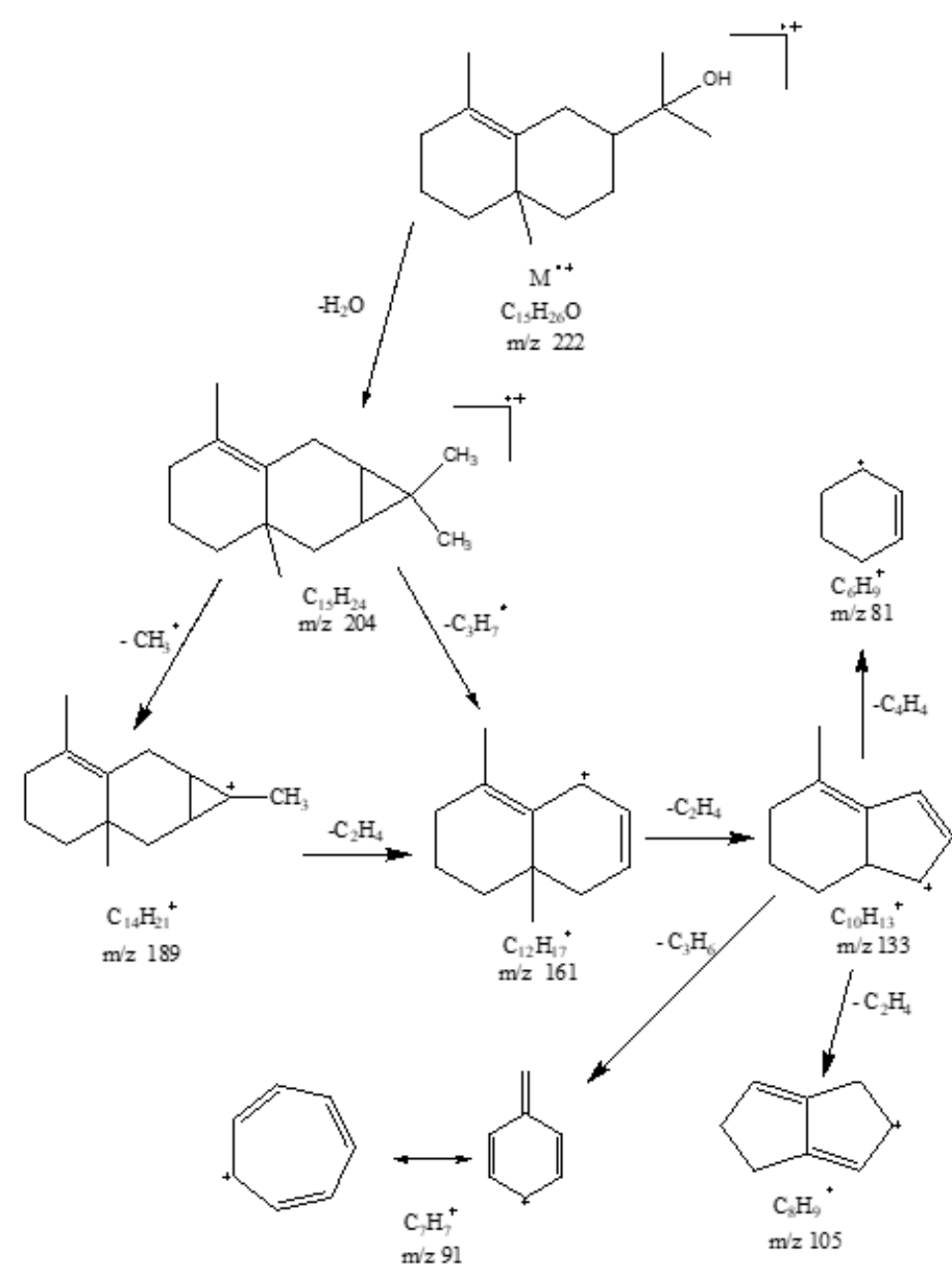

(d) Eudesmol

Scheme 1. Cont. 


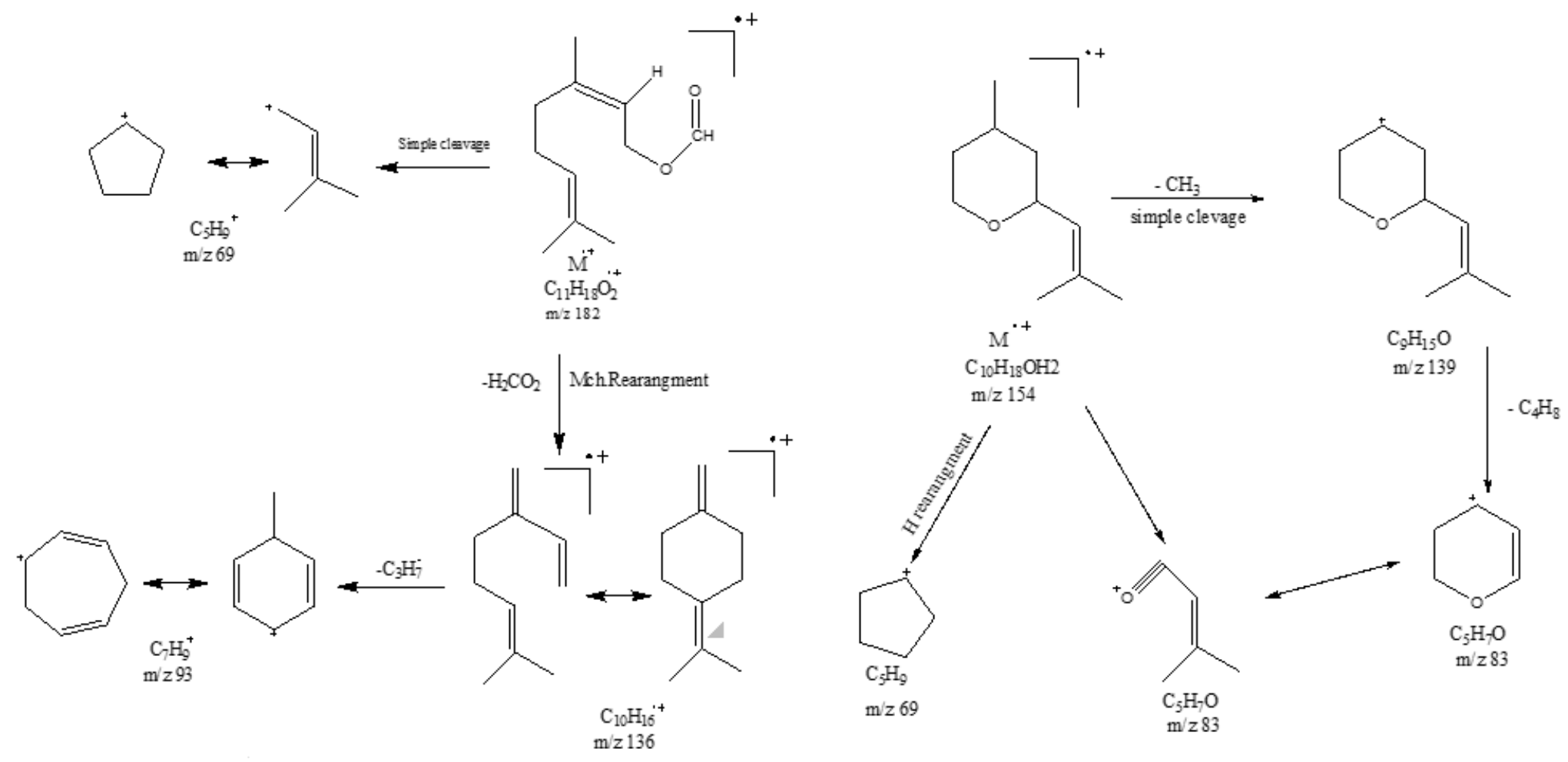

(e) Geraniol formate

(f) Rose oxide

Scheme 1. EI fragmentation pattern of the studied components. 


\section{Computation Method}

The geometry of major essential oil constitutes of $P$. graveolens has been optimized based on the molecular mechanics and semi-empirical calculations implemented in the molecular modelling program HyperChem7.0. program. Semi-empirical calculations were carried out using the routine MNDO and Ploak-Ribiere conjugated gradient algorithm. To optimize the structures, the Ploak-Ribiere conjugated gradient algorithm was used to obtain the molecular properties including heat of formation, ionization energy, highest occupied molecular orbital (HOMO), the energy of the lowest unoccupied molecular orbital (LUMO) energies, dipole moment, atom charges, total energy, binding energy, and nuclear energy of the studied molecules. The calculated thermochemical properties of the studied components considered are shown in Table 1. Note that all studied components (except rose oxide) have high and negative values heats of formation, which indicate that these are thermodynamically stable molecules. The positive value of the heat of formation of rose oxide could be attributed to the presence of a hetero oxygen atom in the six cyclic ring. The different structures of these components are determined based on the lowest energy that stabilizes the structure. The MNDO showed non-planar structures in all components (except rose oxide) as more stable molecules as shown in Figure 3. The total energies of the studied components have been calculated by this quantum chemical method, which is $-42657 \mathrm{kcal}^{\mathrm{mol}}{ }^{-1}$ for rose oxide and $-60183 \mathrm{kcal}^{\mathrm{mol}}{ }^{-1}$ for ç-Eudesmol. Electron affinity (EA) is a measure of the power of the molecule to granting electron when adding the electron LUMO. From Table 1, note that citronellol, linalool, and geraniol formate have the most electron affinities more than other studied components. This could be attributed to their long chain structure and the presence of the single and double oxygen bond, whereas cis-Menthone, eudesmol and rose oxide have the cyclic structure. Further, cis-Menthone and rose oxide have the lowest values $(0.390$ and $0.823 \mathrm{eV}$ ), respectively, because they have a saturated six cyclic structures. In rose oxide molecule, replacing carbon with the oxygen atom in the ring could lead to increased ability of electron affinity of the molecule. The hyper activity of this molecule is confirmed by the largest value of energy gap $(-10.505038 \mathrm{eV})$. In addition, the ionization energies (IEs) for citronellol, linalool, and geraniol formate have nearly the same values $(8.8 \mathrm{eV})$, whereas cis-Menthone has the highest value $(9.5 \mathrm{eV})$ due to the presence of ketone form $\mathrm{C}=\mathrm{O}$ group as well as the lower value of heat of formation $-63 \mathrm{kcal} . \mathrm{mol}^{-1}$. On the other hand, rose oxide has the lowest value $(7.1 \mathrm{eV})$ of ionization energy and at the same time it has the highest value of heat of formation $\left(\Delta H_{F}(\mathrm{M})=110 \mathrm{kcal}^{\mathrm{mol}}{ }^{-1}\right)$. 
Table 1. Thermodynamic data reported of the studied constituents using MNDO method.

\begin{tabular}{|c|c|c|c|c|c|c|c|c|c|}
\hline Compound & $\begin{array}{c}\Delta \mathrm{H}_{\mathrm{F}}(\mathrm{M}) \\
\text { kcal.mol }^{-1}\end{array}$ & $\begin{array}{c}\Delta \mathrm{H}_{\mathrm{F}}(\mathrm{M})^{+} \\
\text {kcal.mol }\end{array}$ & $\Delta \mathrm{H}_{\mathrm{F}}(\mathrm{M})^{-}{ }^{\mathrm{kccal} . \mathrm{mol}^{-1}}$ & EA eV & $\begin{array}{l}\text { Total Energy (M) } \\
\text { kcal.mol }{ }^{-1}\end{array}$ & $\begin{array}{l}\text { Total Energy }(\mathbf{M})^{+} \\
\quad \text { kcal.mol }^{-1}\end{array}$ & I.E eV & $\begin{array}{c}\text { Binding } \\
\text { Energy (M) } \\
\text { kcal.mol }{ }^{-1}\end{array}$ & $\begin{array}{c}\text { Dipole } \\
\text { Moment (M) } \\
\text { D }\end{array}$ \\
\hline 1-Citronellol & -70 & 133 & -69 & -0.043 & -43491 & -43288 & 8.8 & -2880 & 1.4 \\
\hline 2-Linalool & -36 & 165 & -31 & -0.260 & -42803 & -42603 & 8.7 & -2742 & 1.5 \\
\hline 3-cis-Menthone & -63 & 157 & -66 & 0.130 & -42831 & -42610 & 9.5 & -2770 & 2.4 \\
\hline 4-ç-Eudesmol & -54 & 139 & -63 & 0.390 & -60183 & -59991 & 8.4 & -4032 & 1.3 \\
\hline $\begin{array}{l}\text { 5-Geraniol } \\
\text { formate }\end{array}$ & -73 & 132 & -75 & 0.086 & -53181 & -52976 & 8.9 & -3010 & 3.9 \\
\hline 6-Rose oxide & 110 & 275 & 91 & 0.823 & -42657 & -42492 & 7.1 & -2596 & 0.6 \\
\hline
\end{tabular}




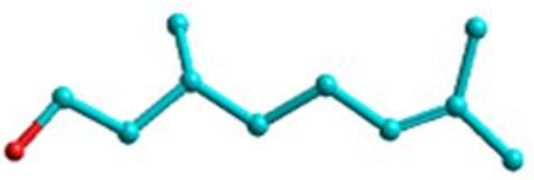

Citronellol
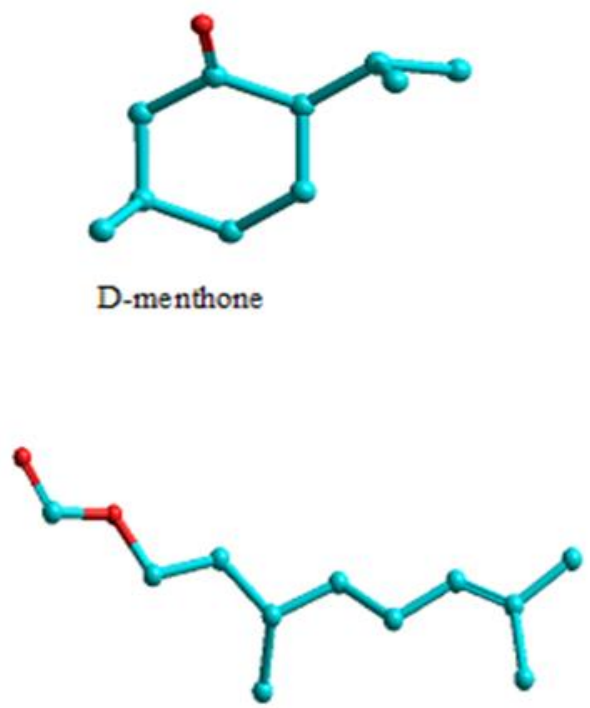

Geraniol formate

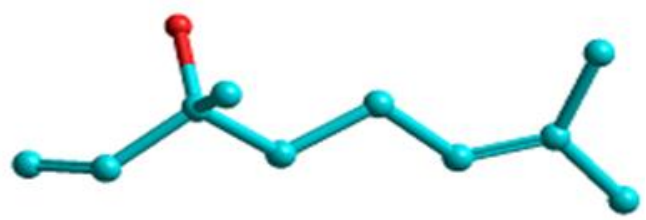

Linalool

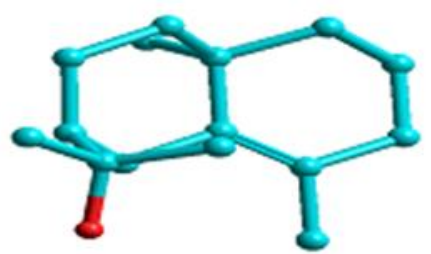

६-Eudesmol

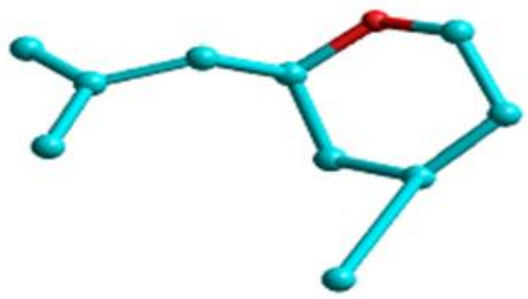

Rose oxide

Figure 3. The optimized structures of the studied constituents using Modified Neglect of Diatomic Overlap (MNDO) method at ground state.

Molecular orbitals (MO's), including the HOMO, LUMO, and the energy gap (Egap), are considered important parameters for quantum chemistry. The way the molecule interacts with other species could be determined, and then named as Frontier Molecular Orbitals (FMOs). HOMO, could be considered as the outermost orbital that contain electrons, and act as electron donor [25]. LUMO is the innermost orbital that have free places accepting electrons. A small frontier orbital gap molecules are more polarizable and associated with a high chemical activity as well as low kinetic stability [26]. To get insight to the energetic behaviour of the studied components, we have performed MNDO method calculations in ground state and the results are shown in Table 2. The 2D plots of the HOMO, LUMO frontier orbitals are depicted in Figure 4. The positive phase is presented in red colour and the negative one is in green. The energy gap of HOMO-LUMO explains the eventual charge transfer interaction within the molecule, the increasing value of the energy gap and of the molecule becomes more stable, as shown in Table 2. cis-Menthone is the most stable molecule with energy gap $9.737401 \mathrm{eV}$.

Table 2. HOMO and LUMO values of the studied compounds using MNDO method.

\begin{tabular}{llll}
\hline Compound & HOMO $(\mathbf{e V})$ & LUMO $(\mathrm{eV})$ & Energy Gap $(\Delta)(\mathrm{eV})$ \\
\hline 1. -Citronellol & -9.621878 & 0.767305 & 8.854573 \\
2. -Linalool & -9.535233 & 0.848275 & 8.686958 \\
3. -cis-Menthone & -10.48469 & 0.747289 & 9.737401 \\
4. -ç-Eudesmol & -9.398919 & 0.718945 & 8.679973 \\
5. -Geraniol formate & -9.72253 & 0.688588 & 9.033941 \\
6. -Rose oxide & -9.383857 & 1.121181 & 8.262676 \\
\hline
\end{tabular}




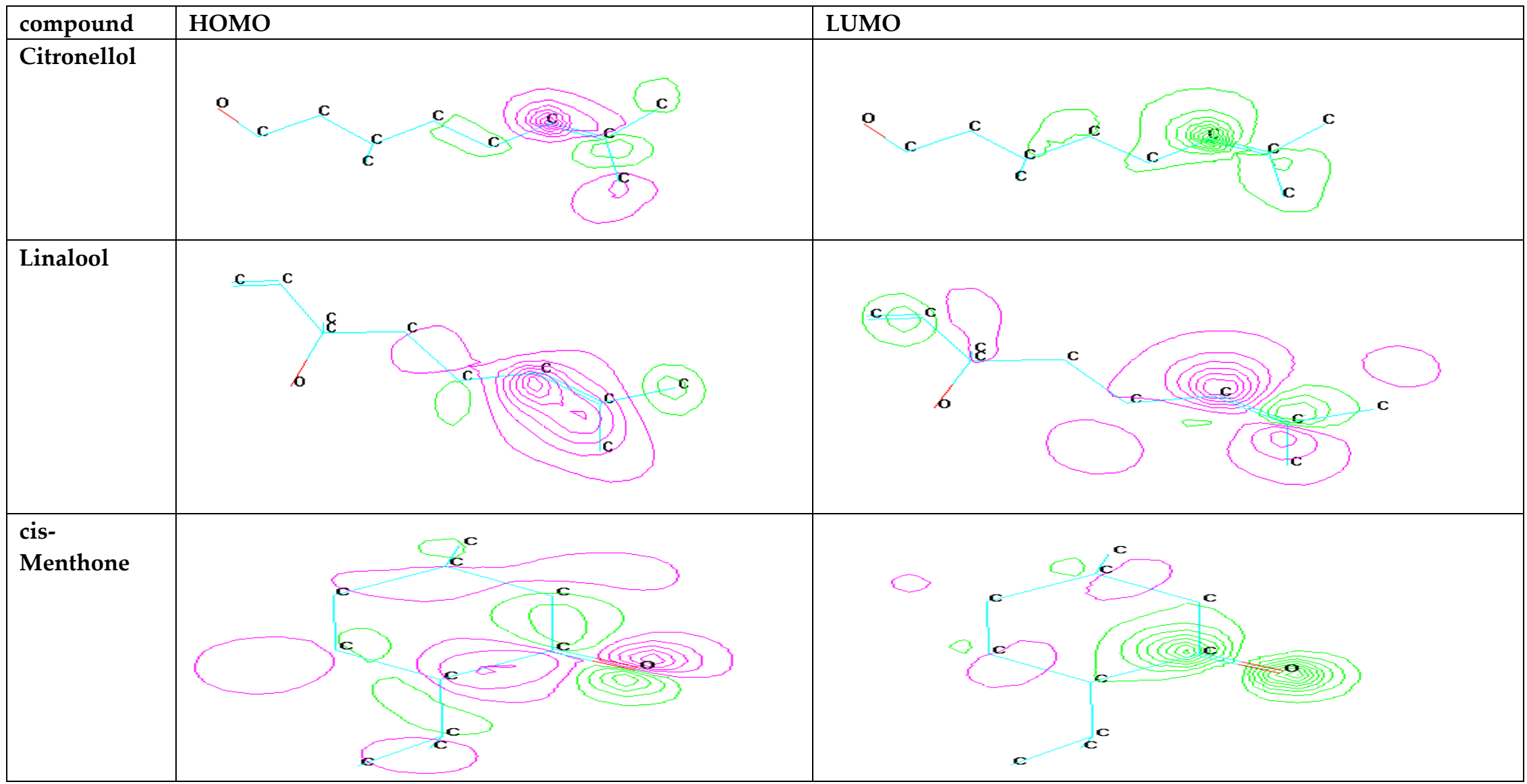

Figure 4. Cont. 


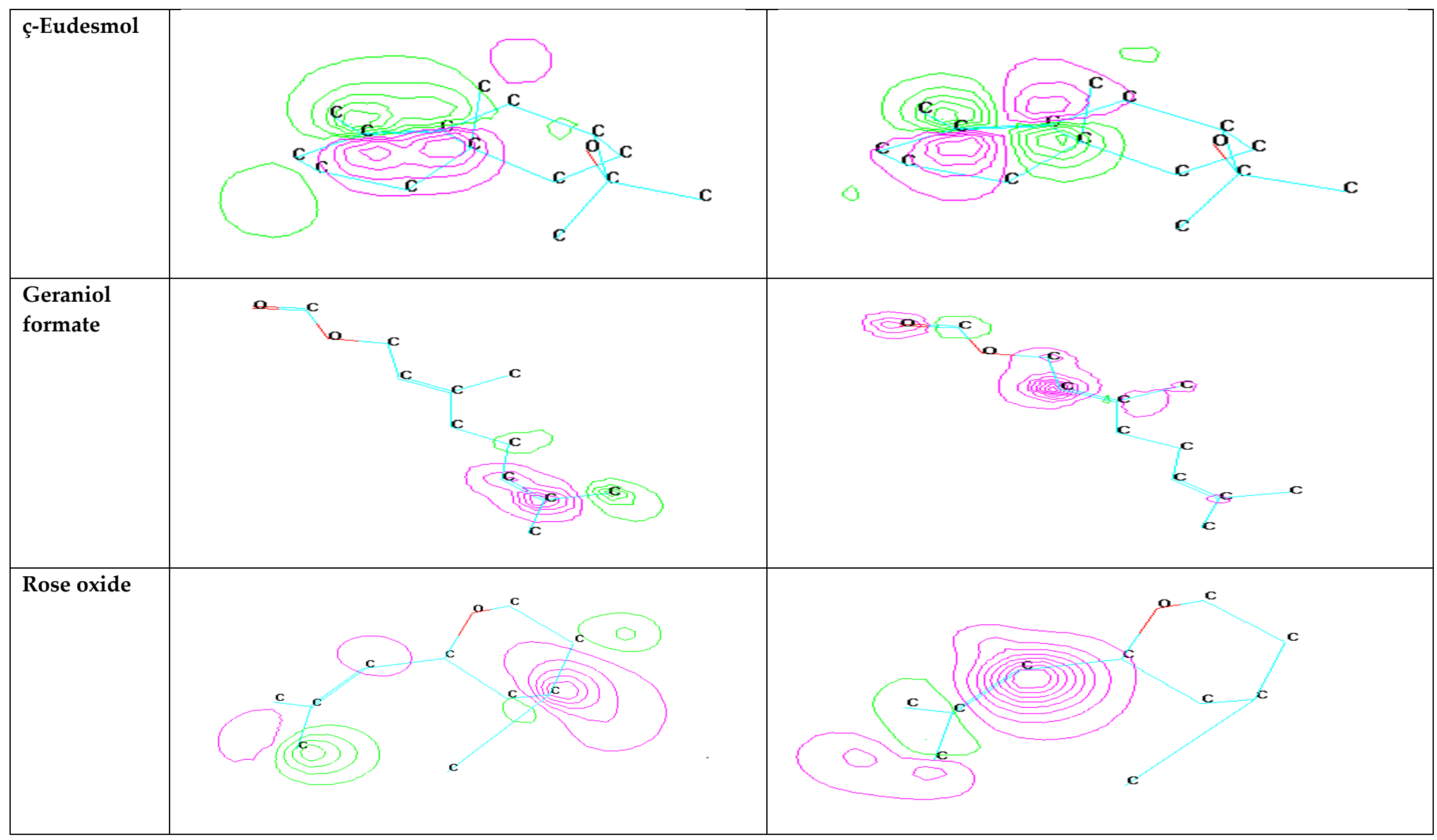

Figure 4. 2D contours HOMO and LUMO of the studied compounds using MNDO method. 
The ionization energy (IE) that resulted from the highest occupied molecular orbital is smaller for all studied molecules except cis-Menthone which have the highest IE $=9.5 \mathrm{eV}$. This could be explained by the presence of a double oxygen bond coupled with the sixth cyclic ring as a ketone group. In addition, rose oxide have the smallest IE $=7.1 \mathrm{eV}$ due to the presence of the oxygen as a hetero atom in the sixth cyclic ring, which carries a positive charge.

The molecule dipole moment is an important electron property which represents a generalized measure of bond properties and charge densities [27]. The dipole moments values of the 1,2,4 molecules (1.4, 1.5 and 1.3 debye) have nearly the same values. This could be explained by the symmetric distribution of the charge atoms of these molecules. A molecule which have electron accepter group because of improved charge distribution and increasing distance have higher dipole moment, which is the case in geraniol formate and cis-Menthone molecules (Table 1), they have higher dipole moment $(3.9,2.4$ Debye). These high values could be attributed to the presence of single and double oxygen bonds in these structures as polar groups. Rose oxide has the lowest dipole moment value (0.6 Debye) because the electronic configuration $(\mathrm{C}-\mathrm{O}-\mathrm{C})$ is nearly homogenous.

\subsection{Possible Correlation Between the Activity and the Semi-Empirical Calculations}

From the calculated heat of formations $\Delta H_{F}(\mathrm{M})$ of the studied components (Table 1), it was obvious that all components have negative values (except rose oxide) that confirm that these components have relatively high stabilities. The dipole moment of the molecule gives information on the polarity of these molecules. The large dipole moment may increase its reactivity. This means that geraniol formate and cis-Menthone have a tendency to interact with other molecules, as shown in Table 1. The energies of HOMO and LUMO are not activity descriptors, but can be connected to the activity of molecules under study. Higher HOMO energies indicate better electron-donating properties of a molecule and the lower HOMO energy point to the lower activity of the molecule (e.g., antioxidant or antimicrobial) $[28,29]$. The values of HOMO, LUMO, and energy gap of the first group are listed in Table 2. It was clear that cis-Menthone, citronellol, and linalool compounds have better electron donating properties and high activities than the other studied compounds which was confirmed by antimicrobial activities assays and had not been studied before in P. graveolens.

\subsection{Antibacterial Activities}

P. graveolens essential oil showed high antibacterial effects against all tested bacteria (Table 3). Individual identified compounds in the essential oil: citronellol, cis-Menthone, and linalool, (except eudesmol) showed comparable activity to antibiotics. Eudesmol was almost inactive at low dosages. The most active isolated compound was the citronellol and the lowest MIC was found against $E$. coli $\left(0.007 \pm 0.0003 \mathrm{mg} \mathrm{mL}^{-1}\right)$. E. coli, L. monocytogenes, and B. cereus were the most sensitive bacteria. In P. graveolens L'Her from Iran, the essential oil showed no activity against $L$. monocytogenes, which could be explained by that major constitutes were completely different than our study ( $\beta$-citronellol 36.4\%) [18]. In Pelargonium roseum from South Africa the major constitute identified was citronellol (39.97-43.67\%) and showed antibacterial effects comparable to antibiotics against $P$. aeruginosa and S. aureus [17]. Previous investigation on citronellol reported comparable bioactivity against $E$. coli and $S$. aureus to that reported here [30]. In Mentha longifolia L. essential oils (menthone 20.7-28.8\%), the antimicrobial study showed MIC ranging from 0.195 to $3.12 \times 10^{3} \mu \mathrm{g} \mathrm{mL}-1$ against most bacteria [31]. In another study, the menthol (structurally related to menthol) showed moderate activity against $E$. coli and others [32]. In agreement with our results, no study revealed obvious antibacterial effects of eudesmol against most bacteria. The bioactivity of the essential oil of P. graveolens against bacteria is mainly attributed to the active compounds within the essential oils including citronellol, cis-Menthone, and linalool only. 
Table 3. Minimum inhibitory (MIC) and bactericidal concentration (MBC) of Pelargonium graveolens leaf extracts $\left(\mathrm{mg} \mathrm{mL}^{-1}\right)$ as well as identified compounds.

\begin{tabular}{ccccccc}
\hline & $\begin{array}{c}\text { P. aeruginosa } \\
\text { MIC MBC }\end{array}$ & $\begin{array}{c}\text { B. cereus } \\
\text { MIC MBC }\end{array}$ & $\begin{array}{c}\text { L. monocytogenes } \\
\text { MIC MBC }\end{array}$ & $\begin{array}{c}\text { E. coli MIC } \\
\text { MBC }\end{array}$ & $\begin{array}{c}\text { M. flavus } \\
\text { MIC MBC }\end{array}$ & $\begin{array}{c}\text { S. aureus } \\
\text { MIC MBC }\end{array}$ \\
\hline $\begin{array}{c}P . \\
\text { graveolens }\end{array}$ & $0.08 \pm 0.01$ & $0.09 \pm 0.01$ & $0.13 \pm 0.01$ & $0.12 \pm 0.01$ & $0.12 \pm 0.01$ & $0.18 \pm 0.02$ \\
\multirow{3}{*}{ Citronellol } & $0.17 \pm 0.01$ & $0.18 \pm 0.01$ & $0.28 \pm 0.02$ & $0.23 \pm 0.02$ & $0.26 \pm 0.02$ & $0.36 \pm 0.03$ \\
& $0.08 \pm 0.01$ & $0.10 \pm 0.01$ & $0.13 \pm 0.01$ & $0.007 \pm$ & $0.15 \pm 0.01$ & $0.2 \pm 0.01$ \\
& $0.20 \pm 0.01$ & $0.24 \pm 0.01$ & $0.29 \pm 0.01$ & $0.016 \pm 0.005$ & $0.31 \pm 0.01$ & $0.44 \pm 0.02$ \\
\hline \multirow{2}{*}{ cis-Menthone } & $0.09 \pm 0.01$ & $0.12 \pm 0.01$ & $0.16 \pm 0.02$ & $0.15 \pm 0.01$ & $0.14 \pm 0.01$ & $0.43 \pm 0.02$ \\
& $0.25 \pm 0.02$ & $0.24 \pm 0.02$ & $0.34 \pm 0.03$ & $0.33 \pm 0.02$ & $0.29 \pm 0.02$ & $0.81 \pm 0.01$ \\
\hline \multirow{2}{*}{ linalool } & $0.31 \pm 0.01$ & $0.23 \pm 0.01$ & $0.17 \pm 0.01$ & $0.25 \pm 0.01$ & $0.20 \pm 0.01$ & $0.21 \pm 0.01$ \\
& $0.59 \pm 0.03$ & $0.52 \pm 0.03$ & $0.34 \pm 0.03$ & $0.55 \pm 0.02$ & $0.41 \pm 0.03$ & $0.43 \pm 0.03$ \\
\hline \multirow{2}{*}{ eudesmol } & $0.39 \pm 0.03$ & $0.48 \pm 0.02$ & $0.79 \pm 0.05$ & $0.38 \pm 0.03$ & $0.79 \pm 0.04$ & $0.48 \pm 0.05$ \\
& $0.86 \pm 0.04$ & $0.92 \pm 0.03$ & $1.79 \pm 0.12$ & $1.03 \pm 0.09$ & $2.36 \pm 0.15$ & $1.63 \pm 0.14$ \\
\hline \multirow{2}{*}{ Streptomycin } & $0.07 \pm 0.01$ & $0.08 \pm 0.01$ & $0.15 \pm 0.01$ & $0.11 \pm 0.01$ & $0.10 \pm 0.01$ & $0.16 \pm 0.02$ \\
& $0.15 \pm 0.01$ & $0.16 \pm 0.02$ & $0.31 \pm 0.03$ & $0.23 \pm 0.02$ & $0.21 \pm 0.02$ & $0.33 \pm 0.02$ \\
\hline
\end{tabular}

\subsection{Antifungal Activities}

Pelargonium roseum essential oils showed high antifungal effects against selected fungi, as shown in Table 4. The MIC and the MFC were relatively low in the experiment. However, the linalool showed the lowest activities against fungi compared to other compounds. cis-Menthone was the most active compound against selected fungi (MIC: from $0.07 \pm 0.01$ to $0.17 \pm 0.01 \mathrm{mg} \mathrm{mL}^{-1}$ ). Also, the eudesmol showed relatively high antifungal activities with MIC ranging from $0.21 \pm 0.01$ to $0.47 \pm 0.02 \mathrm{mg} \mathrm{mL}^{-1}$. The activity of the essential oil of $P$. graveolens is mainly attributed to cis-Menthone, eudesmol, and citronellol only. For our knowledge, this is the first study revealing this conclusion. In a previous investigation, the linalool was active against oral C. albicans at MIC $=1.000 \mathrm{mg} \mathrm{mL}^{-1}$, which is comparable to this study [33]. The analyses of the antifungal activities of the essential oils (mainly composes of eudesmol derivatives) of heartwood in several trees of Cupressaceae, revealed comparable antifungal effects to reference drugs against $C$. albicans [19]. Using the inhibition zone technique, $P$. roseum essential oils were active against most bacteria and a complete inhibition was observed in C. albicans [17].

Table 4. Minimum inhibitory (MIC) and fungicidal concentration (MFC) of Pelargonium graveolens leaf extracts $\left(\mathrm{mg} \mathrm{mL}^{-1}\right)$ as well as identified compounds.

\begin{tabular}{ccccccc}
\hline & $\begin{array}{c}\text { Aspergillus } \\
\text { flavus MIC } \\
\text { MFC }\end{array}$ & $\begin{array}{c}\text { Aspergillus } \\
\text { ochraceus } \\
\text { MIC MFC }\end{array}$ & $\begin{array}{c}\text { Aspergillus } \\
\text { niger MIC } \\
\text { MFC }\end{array}$ & $\begin{array}{c}\text { Candida } \\
\text { albicans } \\
\text { MIC MFC }\end{array}$ & $\begin{array}{c}\text { Penicillium } \\
\text { funiculosum } \\
\text { MIC MFC }\end{array}$ & $\begin{array}{c}\text { Penicillium } \\
\text { ochrochloron } \\
\text { MIC MFC }\end{array}$ \\
\hline $\begin{array}{c}\text { Pelargonium } \\
\text { graveolens }\end{array}$ & $0.23 \pm 0.01$ & $0.24 \pm 0.03$ & $0.25 \pm 0.02$ & $0.23 \pm 0.01$ & $0.21 \pm 0.01$ & $0.23 \pm 0.01$ \\
\hline \multirow{2}{*}{ citronellol } & $0.25 \pm 0.03$ & $0.52 \pm 0.02$ & $0.56 \pm 0.03$ & $0.40 \pm 0.03$ & $0.43 \pm 0.02$ & $0.45 \pm 0.03$ \\
\hline \multirow{2}{*}{ cis-Menthone } & $0.52 \pm 0.03$ & $0.34 \pm 0.02$ & $0.13 \pm 0.01$ & $0.19 \pm 0.01$ & $0.28 \pm 0.02$ & $0.33 \pm 0.01$ \\
& $0.15 \pm 0.01$ & $0.13 \pm 0.03$ & $0.27 \pm 0.03$ & $0.40 \pm 0.03$ & $0.59 \pm 0.03$ & $0.73 \pm 0.04$ \\
\hline \multirow{2}{*}{ linalool } & $0.53 \pm 0.05$ & $0.35 \pm 0.03$ & $0.37 \pm 0.03$ & $0.93 \pm 0.05$ & $0.57 \pm 0.05$ & $0.46 \pm 0.02$ \\
& $1.19 \pm 0.12$ & $0.68 \pm 0.05$ & $0.72 \pm 0.04$ & $1.62 \pm 0.13$ & $1.15 \pm 0.12$ & $0.94 \pm 0.05$ \\
\hline \multirow{2}{*}{ eudesmol } & $0.35 \pm 0.03$ & $0.47 \pm 0.02$ & $0.25 \pm 0.02$ & $0.21 \pm 0.01$ & $0.44 \pm 0.03$ & $0.42 \pm 0.03$ \\
& $0.81 \pm 0.03$ & $0.93 \pm 0.04$ & $0.68 \pm 0.03$ & $0.44 \pm 0.03$ & $0.89 \pm 0.04$ & $0.93 \pm 0.04$ \\
\hline \multirow{2}{*}{ KTZ } & $0.21 \pm 0.02$ & $0.19 \pm 0.01$ & $0.10 \pm 0.01$ & $0.21 \pm 0.02$ & $1.98 \pm 0.10$ & $0.22 \pm 0.01$ \\
& $0.42 \pm 0.03$ & $0.40 \pm 0.03$ & $0.21 \pm 0.02$ & $0.42 \pm 0.02$ & $3.60 \pm 0.09$ & $0.43 \pm 0.03$ \\
\hline
\end{tabular}




\section{Materials and Methods}

Pelargonium graveolens leaf samples were collected from plants growing in Zagazeg University campus in July $2018\left(24-30{ }^{\circ} \mathrm{C}\right)$. The plants were identified at the Botany Department, Faculty of Agriculture, Zagazeg University, Egypt, and a voucher specimen has been created.

\subsection{Essential Oil Extraction}

Dried leaves $(1.5 \mathrm{~kg})$ of P. graveolens were subjected to $3 \mathrm{~h}$ of hydro-distillation in a Clevenger-type apparatus. The oil was separated, then dried under anhydrous sodium sulfate $\left(\mathrm{Na}_{2} \mathrm{SO}_{4}\right)$. The oil was stored in the dark at $6{ }^{\circ} \mathrm{C}$ until further analysis.

\subsection{Gas Chromatography-Mass-Spectrometry Analysis}

A Facous GC-DSQ mass spectrometer (Thermo Scientific, Waltham, MA, USA) was used in the Egyptian Atomic Energy authority, Nuclear Research Centre, Experimental Nuclear Physics Department, Atomic and Molecular Physics Unit. The machine was loaded with A3000 autosampler and TR-5MS Capillary column $(0.25 \mu \mathrm{m}$ film thickness, $30 \mathrm{~m}$ length, and $0.25 \mathrm{~mm}$ i.d.). Temperature increase was from $55^{\circ} \mathrm{C}$ to $200{ }^{\circ} \mathrm{C}\left(5^{\circ} \mathrm{C} \mathrm{min}-1\right)$ and a final temperature of $300{ }^{\circ} \mathrm{C}$. The carrier gas was the helium $\left(1 \mathrm{~mL} \mathrm{~min}^{-1}\right)$. The components were identified tentatively by comparing the retention times and mass spectra with those of WILEY (Wiley, 9th Edition Version 1.02) and NIST 05 (NIST version $2.0 \mathrm{~d}$ ) databases.

\subsection{Antibacterial Activity}

The antibacterial activities against Listeria monocytogenes (clinical isolate), Bacillus cereus (ATCC 14579), Micrococcus flavus (ATCC 10240), Escherichia coli (ATCC 35210), Staphylococcus aureus (ATCC 6538), and Pseudomonas aeruginosa (ATCC 27853) were assayed using the micro-dilution method [20,34]. A bacterial inoculum $(1.0 \times 104 \mathrm{CFU}$ per well $)$ was mixed in microtiter plates with essential oil serial dilutions then incubated at $37^{\circ} \mathrm{C}$ for one day in a rotary shaker. The minimum inhibitory concentration (MIC) and the minimum bactericide concentration (MBC) were determined by subculturing using serial dilutions of essential oil. The optical density was determined at a wavelength of $655 \mathrm{~nm}$. Streptomycin was used as antibiotic at $0.01-10 \mathrm{mg} \mathrm{mL}^{-1}$. This array of bacteria causes several human diseases [35-37].

\subsection{Antifungal Activity}

The leaf extracts antifungal effects were determined using various economically important fungi, including Candida albicans (ATCC 12066), Aspergillus flavus (ATCC 9643), Penicillium ochrochloron (ATCC 48663), A. ochraceus (ATCC 12066), A. niger (ATCC 6275), and Penicillium funiculosum (ATCC 56755). The microdilution technique was used in this assay $[7,20,34]$. Ketoconazole served as positive control $(1-3500 \mu \mathrm{g} / \mathrm{mL})$. Commercial standards (Sigma-Aldrich, Berlin, Germany) were used for comparison reasons.

\section{Conclusions}

This is the first study applying MNDO on P. graveolens essential oil main constitutes and investigating the biological activities of these compounds. The experimental GC-MS data revealed that P. graveolens major constituents were citronellol (27.67\%), cis-Menthone $(10.23 \%)$, linalool $(10.05 \%)$, eudesmol $(9.40 \%)$, geraniol formate $6.87 \%$, and rose oxide $(5.77 \%)$. Using the obtained electron ionization mass spectra of these compounds, the fragmentation processes observed were the loss of $\mathrm{H}_{2} \mathrm{O}$ and $\mathrm{CH}_{3}$ radical, further fragmentation pathways were reported and discussed. These experimental data together with the MNDO revealed in-depth information about the chemical behavior of the studied molecules which are important for many chemical and medical applications. P. graveolens essential oil showed high antibacterial effects against all tested bacteria. The individual identified compounds in the essential oil—citronellol, cis-Menthone, and linalool (except eudesmol)—showed comparable activity 
to antibiotics. The most active isolated compound was the citronellol and the lowest MIC was found against $E$. coli $\left(0.007 \pm 0.0003 \mathrm{mg} \mathrm{mL}^{-1}\right)$. The essential oil showed high antifungal effects. The activity of the essential oil of $P$. graveolens is mainly attributed to cis-Menthone, eudesmol and citronellol only (excluding linalool). For our knowledge, this is the first study revealing this conclusion. cis-Menthone was the most active compound against selected fungi (MIC: from $0.07 \pm 0.01$ to $0.17 \pm 0.01 \mathrm{mg} \mathrm{mL}^{-1}$ ). Also, the eudesmol showed relatively high antifungal activities with MIC ranging from $0.21 \pm 0.01$ to $0.47 \pm 0.02 \mathrm{mg} \mathrm{mL}^{-1}$. The study recommends local $P$. graveolens and identified active compounds for further investigations to explore possible uses in the pharmaceutical industries.

Supplementary Materials: The following are available online at http://www.mdpi.com/2227-9717/8/2/128/s1, Table S1: The chemical composition of P. graveolens essential oil by GC-MS.

Author Contributions: Conceptualization, M.S.M.A.E.-K., M.A.R., and H.O.E.; Data curation, M.S.M.A.E.-K., M.A.R. and H.O.E.; Formal analysis, M.S.M.A.E.-K., M.A.R., and H.O.E.; Funding acquisition, F.A.A.-M.; Investigation, M.S.M.A.E.-K. and F.A.A.-M.; Methodology, M.S.M.A.E.-K., M.A.R., H.O.E., and F.A.A.-M.; Project administration, F.A.A.-M.; Resources, M.S.M.A.E.-K. and F.A.A.-M.; Software, M.A.R. and H.O.E.; Visualization, M.S.M.A.E.-K.; Writing—original draft, M.S.M.A.E.-K., M.A.R., and H.O.E.; Writing-review \& editing, M.S.M.A.E.-K., M.A.R., and H.O.E. All authors have read and agreed to the published version of the manuscript.

Funding: The work was supported by King Saud University, Researchers Supporting Project number (RSP-2019/118).

Acknowledgments: The authors extend their appreciation to King Saud University, Researchers Supporting Project for funding this work through research group (RSP-2019/118). Authors are grateful to the Faculty of Agriculture, Zagazig University. Zagazig city, Egypt, for support. We thank Adham Al-sagheer for his great efforts in sample preparation.

Conflicts of Interest: The authors declare no conflicts of interest.

\section{References}

1. Salem, M.Z.M.; Elansary, H.O.; Ali, H.M.; El-Settawy, A.A.; Elshikh, M.S.; Abdel-Salam, E.M.; Skalicka-Wozniak, K. Bioactivity of essential oils extracted from Cupressus macrocarpa branchlets and Corymbia citriodora leaves grown in Egypt. BMC Complement. Altern. Med. 2018, 18, 23. [CrossRef] [PubMed]

2. Skalicka-Wozniak, K.; Grzegorczyk, A.; Swiatek, L.; Walasek, M.; Widelski, J.; Rajtar, B.; Polz-Dacewicz, M.; Maim, A.; Elansary, H.O. Biological activity and safety profile of the essential oil from fruits of Heracleum mantegazzianum Sommier \& Levier (Apiaceae). Food Chem. Toxicol. 2017, 109, 820-826. [PubMed]

3. Mahmoud, E.A.; Elansary, H.O.; El-Ansary, D.O.; Al-Mana, F.A. Elevated Bioactivity of Ruta graveolens against Cancer Cells and Microbes Using Seaweeds. Processes 2020, 8, 75. [CrossRef]

4. El-Hefny, M.; Mohamed, A.A.; Salem, M.Z.M.; Abd El-Kareem, M.S.M.; Ali, H.M. Chemical composition, antioxidant capacity and antibacterial activity against some potato bacterial pathogens of fruit extracts from Phytolacca dioica and Ziziphus spina-christi grown in Egypt. Sci. Hortic. 2018, 233, 225-232. [CrossRef]

5. Das, S.; Horváth, B.; Šafranko, S.; Jokić, S.; Széchenyi, A.; Kőszegi, T. Antimicrobial Activity of Chamomile Essential Oil: Effect of Different Formulations. Molecules 2019, 24, 4321. [CrossRef] [PubMed]

6. Dosoky, N.S.; Satyal, P.; Barata, L.M.; da Silva, J.K.R.; Setzer, W.N. Volatiles of Black Pepper Fruits (Piper nigrum L). Molecules 2019, 24, 4244. [CrossRef] [PubMed]

7. Elansary, H.O.; Abdelgaleil, S.A.M.; Mahmoud, E.A.; Yessoufou, K.; Elhindi, K.; El-Hendawy, S. Effective antioxidant, antimicrobial and anticancer activities of essential oils of horticultural aromatic crops in northern Egypt. BMC Complement. Altern. Med. 2018, 18, 214. [CrossRef]

8. CharlwoodK, B.V.C.A. Pelargonium spp. (Geranium). In Medicinal and Aromatic Plants III. Biotechnology in Agriculture and Forestry; Bajaj, Y.P.S., Ed.; Springer: Berlin/Heidelberg, Germany, 1991; Volume 15, pp. 339-352.

9. Bouslimani, A.; Sanchez, L.M.; Garg, N.; Dorrestein, P.C. Mass spectrometry of natural products: Current, emerging and future technologies. Nat. Prod. Rep. 2014, 31, 718-729. [CrossRef]

10. Hu, X.; Zheng, Y.; Sun, J.; Shang, L.; Wang, G.; Zhang, H. Simultaneous Quantification of Benazepril, Gliclazide and Valsartan in Human Plasma by LC-MS-MS and Application for Rapidly Measuring Protein Binding Interaction between Rhein and These Three Drugs. Chromatographia 2009, 69, 843-852. [CrossRef] 
11. Bourcier, S.; Hoppilliard, Y. Fragmentation Mechanisms of Protonated Benzylamines. Electrospray Ionisation-Tandem Mass Spectrometry Study and ab Initio Molecular Orbital Calculations. Eur. J. Mass Spectrom. 2003, 9, 351-360. [CrossRef]

12. Husch, T.; Reiher, M. Comprehensive Analysis of the Neglect of Diatomic Differential Overlap Approximation. J. Chem. Theor. Comput. 2018, 14, 5169-5179. [CrossRef]

13. Tamara, H.; Alain, C.; Vaucher, M.R. Semiempirical molecular orbital models based on the neglect of diatomic differential overlap approximation. Int. J. Quantum Chem. 2018, 118, e25799.

14. Gieseking, R.L.M.; Ratner, M.A.; Schatz, G.C. Benchmarking Semiempirical Methods to Compute Electrochemical Formal Potentials. J. Phys. Chem. A 2018, 122, 6809-6818. [CrossRef] [PubMed]

15. Andrade, M.A.; Cardoso, M.G.; Batista, L.R.; Freire, J.M.; Nelson, D.L. Antimicrobial activity and chemical composition of essential oil of Pelargonium odoratissimum. Rev. Bras. Farmacogn. 2011, 21, 47-52. [CrossRef]

16. Moutaouafiq, S.; Farah, A.; Ez Zoubi, Y.; Ghanmi, M.; Satrani, B.; Bousta, D. Antifungal Activity of Pelargonium graveolens Essential Oil and its Fractions against Wood Decay Fungi. J. Essent. Oil Bear. Plants 2019, 22, 1104-1114. [CrossRef]

17. Carmen, G.; Hancu, G. Antimicrobial and Antifungal Activity of Pelargonium roseum Essential Oils. Adv. Pharm. Bull. 2014, 4 (Suppl. 2), 511-514.

18. Ghannadi, A.; Bagherinejad, M.; Abedi, D.; Jalali, M.; Absalan, B.; Sadeghi, N. Antibacterial activity and composition of essential oils from Pelargonium graveolens L'Her and Vitex agnus-castus L. Iran. J. Microbiol. 2012, 4, 171-176.

19. Waikedre, J.; Vitturo, C.I.; Molina, A.; Theodoro, P.N.E.T.; do Rosário Rodrigues Silva, M.; Espindola, L.S.; Maciuk, A.; Fournet, A. Antifungal Activity of the Essential Oils of Callitris neocaledonica and C. sulcata Heartwood (Cupressaceae). Chem. Biodivers. 2012, 9, 644-653. [CrossRef]

20. Elansary, H.O.; Szopa, A.; Kubica, P.; Ekiert, H.; Ali, H.M.; Elshikh, M.S.; Abdel-Salam, E.M.; El-Esawi, M.; El-Ansary, D.O. Bioactivities of Traditional Medicinal Plants in Alexandria. Evid. Based Complement. Altern. Med. 2018, 2018, 1463579. [CrossRef]

21. Elansary, H.O.; Zin El-Abedin, T.K. Omeprazole alleviates water stress in peppermint and modulates the expression of menthol biosynthesis genes. Plant Physiol. Biochem. 2019, 139, 578-586. [CrossRef]

22. Elansary, H.O. Tree Bark Phenols Regulate the Physiological and Biochemical Performance of Gladiolus Flowers. Processes 2020, 8, 71. [CrossRef]

23. Rana, V.S.; Juyal, J.P.; Amparo Blazquez, M. Chemical constituents of essential oil of Pelargonium graveolens leaves. Int. J. Aromather. 2002, 12, 216-218. [CrossRef]

24. Boukhris, M.; Simmonds, M.S.J.; Sayadi, S.; Bouaziz, M. Chemical Composition and Biological Activities of Polar Extracts and Essential Oil of Rose-scented Geranium, Pelargonium graveolens. Phytother. Res. 2013, 27, 1206-1213. [CrossRef] [PubMed]

25. Bendjeddou, A.; Abbaz, T.; Drissi, S.M.; Gouasmia, A.; Villemin, D. Quantum Chemical Studies on Molecular Structure and Reactivity Descriptors of A Series of Trimethyltetrathiafulvalene Functionalized by Conjugated Substituent. J. Adv. Chem. Sci. 2016, 2, 318-322.

26. Lewis, D.F.V.; Ioannides, C.; Parke, D.V. Interaction of a series of nitriles with the alcohol-inducible isoform of P450: Computer analysis of structure-activity relationships. Xenobiotica 1994, 24, 401-408. [CrossRef] [PubMed]

27. Cammi, R. The Role of Computational Chemistry in the Experimental Determination of the Dipole Moment of Molecules in Solution. J. Comput. Chem. 2019, 40, 2309-2317. [CrossRef]

28. Świsłocka, R.; Regulska, E.; Karpińska, J.; Świderski, G.; Lewandowski, W. Molecular Structure and Antioxidant Properties of Alkali Metal Salts of Rosmarinic Acid. Experimental and DFT Studies. Molecules 2019, 24, 2645. [CrossRef]

29. Coulibaly, W.N.D.J.; Koné, M.; Dago, C.; Ambeu, C.; Bazureau, J.; Ziao, N. Studies of the Chemical Reactivity of a Series of Rhodanine Derivatives by Approaches to Quantum Chemistry. Comput. Mol. Biosci. 2019, 9, 49-62. [CrossRef]

30. Lopez-Romero, J.C.; Gonzale- Ríos, H.; Borges, A.; Simões, M. Antibacterial Effects and Mode of Action of Selected Essential Oils Components against Escherichia coli and Staphylococcus aureus. Evid. Based Complement. Altern. Med. 2015, 2015, 9. [CrossRef] 
31. Hajlaoui, H.; Snoussi, M.; Ben Jannet, H.; Mighri, Z.; Bakhrouf, A. Comparison of chemical composition and antimicrobial activities of Mentha longifolia L. ssp.longifolia essential oil from two Tunisian localities (Gabes and Sidi Bouzid). Ann. Microbiol. 2008, 58, 513-520. [CrossRef]

32. Inouye, S.; Takizawa, T.; Yamaguchi, H. Antibacterial activity of essential oils and their major constituents against respiratory tract pathogens by gaseous contact. J. Antimicrob. Chemother. 2001, 47, 565-573. [CrossRef] [PubMed]

33. Dias, I.J.; Trajano, E.R.I.S.; Castro, R.D.; Ferreira, G.L.S.; Medeiros, H.C.M.; Gomes, D.Q.C. Antifungal activity of linalool in cases of Candida spp. isolated from individuals with oral candidiasis. Braz. J. Biol. 2018, 78, 368-374. [CrossRef] [PubMed]

34. Elansary, H.O.; Yessoufou, K.; Shokralla, S.; Mahmoud, E.A.; Skaicka-Wozniak, K. Enhancing mint and basil oil composition and antibacterial activity using seaweed extracts. Ind. Crops Prod. 2016, 92, 50-56. [CrossRef]

35. Miltiadous, G.; Elisaf, M. Native valve endocarditis due to Micrococcus luteus: A case report and review of the literature. J. Med. Case Rep. 2011, 5, 251. [CrossRef]

36. Temple, M.E.; Nahata, M.C. Treatment of Listeriosis. Ann. Pharmacother. 2000, 34, 656-661. [CrossRef]

37. Tewari, A.; Abdullah, S. Bacillus cereus food poisoning: International and Indian perspective. J. Food Sci. Technol. 2015, 52, 2500-2511. [CrossRef]

(C) 2020 by the authors. Licensee MDPI, Basel, Switzerland. This article is an open access article distributed under the terms and conditions of the Creative Commons Attribution (CC BY) license (http://creativecommons.org/licenses/by/4.0/). 